\title{
Correction to: Electric signals counterbalanced posterior vs anterior PTEN signaling in directed migration of Dictyostelium
}

\author{
Bing Song ${ }^{1,2^{*}} \mathbb{0}$, Yu Gu${ }^{1}$, Wenkai Jiang ${ }^{1,2}$, Ying Li ${ }^{1,3}$, Wayne Nishio Ayre ${ }^{1}$, Zhipeng Liư ${ }^{3}$, Tao Yin ${ }^{3}$,
} Christopher Janetopoulos ${ }^{4}$, Miho lijima ${ }^{5}$, Peter Devreotes ${ }^{5}$ and Min Zhao ${ }^{6,7^{*}}$

\section{Correction to: Cell Biosci (2021) 11:111} https://doi.org/10.1186/s13578-021-00580-x In this article, the affiliation 'Department of Ophthalmology \& Vision Science, UC Davis, School of Medicine, Davis CA 95618, USA' for Author Min Zhao was missing.

The affiliation has been updated above and the original article [1] has been corrected.

\begin{abstract}
Author details
${ }^{1}$ School of Dentistry, College of Biomedical and Life Sciences, Cardiff University, CF14 4XY Cardiff, UK. ${ }^{2}$ State Key Laboratory of Military Stomatology, Department of Operative Dentistry \& Endodontics, School of Stomatology, Fourth Military Medical University, Xi'an, China. ${ }^{3}$ Chinese Academy of Medical Sciences \& Peking Union Medical College Institute of Biomedical Engineering, Tianjin, China. ${ }^{4}$ Biolmaging Core Facility, University of Sciences, Philadelphia, PA 19104, USA. ${ }^{5}$ School of Medicine, Johns Hopkins University, Baltimore, MD 21205, USA. ${ }^{6}$ Department of Ophthalmology \& Vision Science, UC Davis, School of Medicine, Davis CA 95618, USA. ${ }^{7}$ Department of Dermatology, UC Davis, School of Medicine, Davis CA 95618, USA.
\end{abstract}

Accepted: 8 July 2021

Published online: 21 July 2021

\author{
Reference \\ 1. Song B, Gu Y, Jiang W, Li Y, Ayre WN, Liu Z, Yin T, Janetopolous C, lijima \\ $M$, Devreotes P, Zhao M. Electric signals counterbalanced posterior vs \\ anterior PTEN signaling in directed migration of Dictyostelium. Cell Biosci. \\ 2021;11:111. https://doi.org/10.1186/s13578-021-00580-x.
}

\section{Publisher's Note}

Springer Nature remains neutral with regard to jurisdictional claims in published maps and institutional affiliations.

The original article can be found online at https://doi.org/10.1186/s13578021-00580-x

*Correspondence: SongB3@cardiff.ac.uk; minzhao@ucdavis.edu

${ }^{1}$ School of Dentistry, College of Biomedical and Life Sciences, Cardiff University, CF14 4XY Cardiff, UK

${ }^{6}$ Department of Ophthalmology \& Vision Science, UC Davis, School of Medicine, Davis CA 95618, USA

Full list of author information is available at the end of the article

(C) The Author(s) 2021. Open Access This article is licensed under a Creative Commons Attribution 4.0 International License, which permits use, sharing, adaptation, distribution and reproduction in any medium or format, as long as you give appropriate credit to the original author(s) and the source, provide a link to the Creative Commons licence, and indicate if changes were made. The images or other third party material in this article are included in the article's Creative Commons licence, unless indicated otherwise in a credit line to the material. If material is not included in the article's Creative Commons licence and your intended use is not permitted by statutory regulation or exceeds the permitted use, you will need to obtain permission directly from the copyright holder. To view a copy of this licence, visit http://creativecommons.org/licenses/by/4.0/. The Creative Commons Public Domain Dedication waiver (http://creativeco mmons.org/publicdomain/zero/1.0/) applies to the data made available in this article, unless otherwise stated in a credit line to the data. 